\title{
The effect of CEO power on bank risk: Do boards and institutional investors matter?+
} By

Yener Altunbaş

The Business School, Bangor University, College Road, Bangor, Gwynedd LL57 2DG, UK

John Thornton*,

Office of Technical Assistance, United States Department of the Treasury, 1750 Pennsylvania Ave NW, Washington DC 20006, USA

Yurtsev Uymaz

Norwich Business School, University of East Anglia, Norwich Research Park, Norwich NR4 7TJ, UK

\begin{abstract}
We test for a link between CEO power and risk taking in US banks. Banks are more likely to take risks if they have powerful CEOs and relatively poor balance sheets. There is little evidence that executive board size and independence have a dampening effect on the channels through which powerful CEOs influence risk-taking and some evidence that institutional investors reinforce the risk-taking preferences of powerful CEOs.
\end{abstract}

Key words: Banks, governance, risk, CEO power, boards of directors, institutional investors

Wordcount: 2499

*Corresponding author. Email: John.Thornton@ otatreas.us; j.thornton@ bangor.ac.uk; Tel: 1202 3558637

+We are grateful to anonymous referee for comments that improved the paper. 


\section{The effect of CEO power on bank risk: do boards and institutional investors matter?}

\section{Introduction}

Banks are prone to risk-taking due to their high leverage, limited creditor market discipline (reflecting deposit insurance and too-big-to-fail guarantees), and the ability to increase rapidly and opaquely the riskiness of their assets. Moreover, bank failures can be costly to the taxpayer and have adverse effects on the real economy. Not surprisingly therefore, there is considerable academic and regulatory debate on the extent to which governance failures have contributed to the risk exposures of banks. For example, it is a widely held view that the vulnerability of banking sector during the crisis that started in 2008 was at caused by a build-up of excessive risk (Brunnermeier, 2009; DeYoung et al., 2013).

In a recent survey of the governance and risk literature, Srivastav and Hagendorff (2016) suggest that shareholder-focused governance exacerbates bank risk-taking and that mechanisms are needed to safeguard the interests of other stakeholders. Building on that literature, we examine whether stakeholders also need protection from the risk-taking preferences of powerful CEOs. Specifically, we examine how the executive board and institutional investor pillars of governance interact with CEO power to mitigate or neutralize the effect of CEO power on bank risk. We find that CEO power is associated with an increase in risk-taking on several measures of bank risk and little evidence that this power is mitigated by banks' board characteristics. We also find evidence that risk-taking by powerful CEOs is encouraged by institutional investors. 
Our results contribute to several branches of the banking literature. First, we contribute to the literature on the determinants of bank risk (for a review see Altunbaş et al., 2017) by showing that CEO power is a significant driver of bank risk-taking on several risk measures. Second, we contribute to the debate on governance in banking (see Srivastav and Hagendorff, 2016) by providing evidence suggesting that bank boards do little to dampen risk-taking by banks in the

face powerful CEOs. Third, we contribute to the literature on CEO power, which has shown that powerful CEOs can impact financial performance (Adams et al., 2005), earnings management practices (Ali and Zhang 2015), dividend policy (Onali et al., 2017), corporate acquisitions (Malmendier and Tate 2008), incentive contract design (Morse et al, 2011), the composition of boards of directors (Combs et al., 2007), and the likelihood of engaging in financial misconduct (Altunbaş et al., 2018); our results suggest that powerful CEOs also encourage greater bank risktaking. Finally, we contribute to the 'monitoring v short-termism' debate on the role of institutional investors (see Callen and Fang, 2013) by showing that institutional investors appear to favor greater risk-taking by CEOs.

\section{Related literature}

The literature on the role of CEO power and the roles of executive boards and institutional investors in bank risk-taking is relatively limited and ambiguous. Agency theory suggests that CEOs have reason to select safer assets than shareholders prefer because CEO wealth comprises tangible and financial assets and human capital concentrated in the firms that they manage, whereas shareholders can diversify their risk in the capital market (Pathan 2009; May 1995). The empirical evidence on the impact of CEOs on bank risk is mixed. For example, Pathan (2009) 
reports that powerful CEOs in US bank holding companies can control board decisions in a way that reduces risk-taking; and Victoravich et al. (2011) report that powerful CEOs reduce risktaking in US banks when controlling for CEO equity compensation; they suggest that CEOs influence board decision-making to reduce risk. On the other hand, Lewellyn and Muller-Kahle (2012) find that powerful CEOs were associated with excessively risky lending practices in a matched pair sample of US firms where half the firms specialized in subprime lending; and Adams et al. (2005) show that firms with more powerful CEOs pursue policies which result in riskier outcomes and suggest that powerful CEOs influence board decisions toward pursuing risky policies.

The board of directors is the cornerstone of the internal governance framework (Fama and Jensen 1983) monitoring executives over the impact of policies on risk and evaluating whether current and future risk-exposure is consistent with risk appetite. However, empirical research on the impact of board characteristics on bank risk-taking is still in its infancy (Srivastav and Hagendorff 2016). ${ }^{1}$ Pathan (2009) reports that smaller boards increase bank risk-taking, but that boards characterized by a higher fraction of independent directors pursue less risky policies. Akhigbe and Martin (2006) show that firms with independent boards see a decline in their stock volatility over the long term. Erkens et al. (2012) find no impact of board independence on bank risk during the 2008-2010 financial crisis for a sample of large international banks. Finally, Beltratti and Stulz (2012) show that banks with a shareholder-friendly board are more disposed to risk taking on some measures of risk.

\footnotetext{
1 Much of the research in this area has been derived from non-financial firms (e.g., Adams and Ferreira 2008; Harris and Raviv; Hermalin and Weisbach, $1998)$.
} 
Institutional investors also have an ambiguous role in bank governance. One the one hand, they can contribute to good governance because they have an incentive to collect information and monitor and discipline management to ensure that the firm's investment strategy is consistent with the objective of maximizing long-term value, rather than meeting short term earnings goals (Shleifer and Vishny, 1986, 1987; Monks and Minow,1985). On the other hand, monitoring may be costly such that institutional investors sell off their investments in response to unfavorable developments (Manconi et al, 2012). In addition, institutional investors themselves may place excessive emphasis on short-term performance, causing management to be overly concerned that near-term earnings (Yan and Zhang, 2009; Manconi et al., 2012). Callen and Fang (2013) review empirical evidence that supports both sides of 'monitoring v short-termism' debate.

\section{Model and data}

Our baseline specification is the following panel regression:

(1) $r_{i t}=\beta_{0}+\beta_{1} C E O P_{i t}+\beta_{2} B S I Z E_{i t}+\beta_{3} B I N D E P_{i t}+\beta_{4} I I N V_{i t}+\delta X_{i t-1}+D_{t}+\varepsilon_{i}$

The dependent variable, $r_{i t}$, measures the risk of bank $i$ in period $t$. We employ three measures of bank risk widely used in the banking literature (see , for example, Altunbaş et al., 2017). The first measure is default risk as indicated by the z-score of each bank, which equals the return on assets plus the capital asset ratio divided by the standard deviation of asset returns. The $\mathrm{z}$ score measures the distance from insolvency where insolvency is defined as a state in which losses surmount 
equity $(\mathrm{E}<-\pi)$ (where $\mathrm{E}$ is equity and $\pi$ is profits). Following the literature, we define the inverse of the probability of insolvency as the z-score such that a higher z-score indicates that the bank is more stable. The second measure is systematic risk, which describes the average stock market reaction of each bank to movements on the overall stock market index. It is constructed using a simple capital asset pricing model, based on the following equation: $R_{i t}=\beta_{0}+\beta_{1} R_{t}+\beta_{2} i n t_{t}+$ and $i n t_{t}$ is the yield on the three-month Treasury bill rate at time (trading day) $t . \beta_{0}$ is the intercept; $\beta_{1}$ is the systematic risk of bank $i$ at time $t$; and $\beta_{2}$ is the interest rate risk. The final measure is systemic risk, which captures the reaction of individual banks to systemic events. This is estimated via the marginal expected shortfall (MES) following the model by Acharya et al. (2017) at a standard risk level of $5 \%$ as follows: $M E S_{i}^{5 \%}=1 /$ days $\sum_{t} R_{i}$ where $M E S_{i}^{5 \%}$ is the marginal expected shortfall of bank $\mathrm{i}$ in $5 \%$ worst days; days is the number of $5 \%$ worst days in the market; $R_{i}$ is the average return of bank $\mathrm{i}$ in $5 \%$ worst days.

Of the independent variables, $C E O P_{i t}$ is an index of $\mathrm{CEO}$ power calculated by applying principal components analysis to four proxies of CEO power: CEO tenure, where a CEOs' power is expected to increase with length of tenure because it helps build decision-making autonomy (Combs et al., 2007); CEO/Chair duality, where the same person holding the CEO and Chair positions simultaneously increases CEO power because it diminishes the role of the board of directors in controlling CEO decisions (Hermalin and Weisbach, 1998); whether a CEO is also an investor in the firm, because the 'convergence of interests' hypothesis predicts that share ownership binds the CEO's economic interests with those of shareholders and provides the CEO with an incentive to maximise firm performance (Fama and Jensen, 1983); and the size of a CEO's network because networks have been viewed as a means for executives to protect each other on 
their respective boards (El-Khatib et al., 2015). The coefficients for each component of the CEO power index, their eigenvalues, and the proportion of the variance explained are reported in Table A1. Our executive board characteristics are $B S I Z E_{i t}$ and $B I N D E P_{i t}$ which represent board size (the number of directors) and board independence (the percent of outside directors), respectively, and $I I N V_{i t}$ is the proportion of equity held in a bank by institutional shareholders. $X_{i t-1}$ is a vector of other bank-specific characteristics commonly employed in the bank risk literature that includes measures of bank capital, leverage, profitability, liquidity, and asset quality. Finally, $D_{t}$ is a dummy variable equal to 1 during 2008 to 2010 and zero otherwise to capture the effects on risk of the worst of the financial crisis on measures of risk.

Our dataset focuses on public listed US banks because of the additional information disclosure regulations that apply to them. For each bank, we gather information on the characteristics of CEOs (tenure, ownership, duality, network size) and executive boards (size and independence) from BoardEx. We match this with information on bank level variables (capital, liquidity, loan provisions, leverage, profitability and size) from Federal Reserve call reports and SNL Financial, which uses company filings. Market information on daily stock price shares outstanding to calculate the bank risk proxies is collected from Bloomberg. From these sources, we are able to construct a panel of 960 banks for the period 1998-2015. Summary statistics for the variables are presented in Table 1 and definitions and sources are given in Table A2. We initially estimate equation (1) using fixed time and bank effects with the bank-specific variables lagged one period to mitigate possible endogeneity bias. This might result, for example, from inverse causality between some covariates and the dependent variable (e.g., banks with a reputation for excessive risk-taking might deter powerful CEOs) and omitted variable bias. Accordingly, we also present 
results using the dynamic Generalized Method of Moments (GMM) panel methodology to obtain consistent estimates (Arellano and Bond,1991; Blundell and Bond 1998).

\section{Empirical results}

Table 2 provides the baseline fixed effects and system GMM estimates of equation (1) for each measure of bank risk. In the system GMM results, the Sargan and Hansen test statistics indicate, respectively, that there is no second order serial correlation and that the instruments used are not correlated with the residuals. The overall impression from both sets of results is that the interests of powerful CEOs and institutional investors are aligned in that both favour greater risk-taking, and that executive boards have only a very modest influence in mitigating bank risk taking. The coefficients on CEO power are positive and statistically significant in both sets of estimates and for each measure of risk. The coefficients on board size are negative but only significant in the estimates for default risk; the coefficients on board independence are negative and significant on each measure of risk in the GMM estimates, but only for systematic risk in the fixed effects estimates. Finally, the coefficients on institutional investors are positive and significant for each measure of risk in the GMM estimates and for systematic risk in the case of the fixed effects estimates. The coefficients on the other bank specific variables in Table 2 suggest that bank risk taking is more likely in larger banks that have relatively weak balance sheets (greater leverage, poorer asset quality, less capital and liquidity, and less profitable), and that risk-taking increased during the financial crises. The economic magnitude of the coefficients on CEO power, the board characteristics and institutional ownership is illustrated in Panel A of Table 5. The table shows the impact on risk of a one standard deviation change in each of these variables. For example, such a change in CEO power is associated with a percentage point increase of between 0.13 to 1.18 in 
default risk, 0.04 to 0.30 in systematic risk, and 0.31 to 0.07 in systematic risk. In the few cases where the coefficients are statistically significant, the magnitudes of the impact of executive board characteristics is generally smaller than that for CEO power, suggesting that boards have only a modest dampening impact on CEO risk-taking. The positive impact on risk-taking of institutional investors is generally smaller than that of CEO power though in the same direction.

We are also interested in whether the effect of CEO power on risk-taking differs across banks depending on board characteristics and the degree of institutional shareholders - that is, whether they dampen or neutralize the impact of CEO power on bank risk taking as this could have implications for policies aimed at reducing risk taking. To this end, we report regression results that include interaction terms for CEO power and board characteristics and for CEO power and institutional ownership. In these estimates, the coefficients on the interaction terms reflect the conditional effects of board characteristics and institutional shareholders on bank risk taking. The results for the executive board characteristic interactions are reported in Table 3 and provide little evidence of conditional effects of boards on risk-taking by powerful CEOs. The coefficients on the board interaction terms are only statistically significant in the fixed effects estimates for systemic risk. The economic magnitude of these coefficients is shown in panel B of Table 5 which indicates that the impact of a one standard deviation change in CEO power on bank risk is dampened by only about 0.02 percentage points in each case. The results for the CEO power and institutional investor interaction are reported in Table 4; they provide some evidence of a positive conditioning effect of institutional investors on powerful CEOs in the case of systemic risk-taking. In all of these estimates (tables 3 and 4), the coefficient on CEO power remains positive and statistically significant in both sets of estimates for each measure of risk each case. 


\section{Conclusions}

We examine the effect of CEO power on risk-taking in US banks and whether that power is conditioned by executive board characteristics and banks institutional investors with regard to risktaking. Our results indicate that banks engage in greater risk-taking activity across several measures of risk if the CEO is powerful. We find little evidence that executive board size and independence have a dampening effect on the channels through which powerful CEOs influence risk-taking and some evidence that institutional investors reinforce the risk-taking preferences of powerful CEOs. Our results suggest that the interests of powerful bank CEOs and institutional investors in banks are generally aligned when it comes to risk-taking and that powerful CEOs are able to influence board decisions toward pursuing risky policies. 


\section{References}

Adams, R.B., Almeida, H., Ferreira, D., 2005. Powerful CEOs and their impact on corporate performance. Review of Financial Studies 18, 1403-1432.

Acharya, V.V., Pedersen, L.H., Philippon, T., Richardson, M., 2017. Measuring systemic risk. The Review of Financial Studies 30, 2-47.

Adams, R.B., Ferreira, D., 2005. A theory of friendly boards. Journal of Finance 62, 217-250.

Akhigbe, A., Martin, A.D., 2006. Valuation impact of Sarbanes-Oxley: Evidence from disclosure and governance within the financial services industry. Journal of Banking and Finance 30, 989-1006.

Ali, A., Zhang, W., 2015. CEO tenure and earnings management. Journal of Accounting and Economics 59, 60-79.

Altunbaş, Y., Thornton, J., Uymaz, Y., 2018. CEO tenure and corporate misconduct: evidence from US banks. Finance Research Letters 26, 1-8.

Altunbaş, Y., Manganelli, S., Marques-Ibanez, D., 2017. Realized bank risk during the great recession. Journal of Financial Intermediation 32, 29-44.

Arellano, M., Bond, S., 1991. Some tests of specification for panel data: Monte Carlo evidence and an application to employment equations. Review of Economic Studies 58, 277-297.

Beltratti, A. Stulz, R. M., 2012. The credit crisis around the globe: Why did some banks perform better? Journal of Financial Economics 105, 1-17.

Blundell, R., Bond, S., 1998. Initial conditions and moment restrictions in dynamic panel data models. Journal of Econometrics 87, 115-143.

Brunnermeier, M. K., 2009. Deciphering the liquidity and credit crunch 2007-08. Journal of 
Economic Perspectives 23, 77-100.

Callen, J.L., Fang, X., 2013. Institutional investor stability and crash risk: Monitoring versus shorttermism? Journal of Banking and Finance 37, 3047-3063.

Combs, J.G., Ketchen Jr, D.J., Perryman, A.A., Donahue, M.S., 2007. The moderating effect of CEO power on the board composition-firm performance relationship. Journal of Management Studies 44, 1299-1323.

DeYoung, R., Peng, E. Y., Yan, M., 2013. Executive compensation and business policy choices at US commercial banks, Journal of Financial and Quantitative Analysis 48, 165-196.

El-Khatib, R., Fogel, K., Jandik, T., 2015. CEO network centrality and merger performance. Journal of Financial Economics 116, 349-382.

Erkens, D. H., Hung, M., Matos, P., 2012. Corporate governance in the 2007-2008 financial crisis: evidence from financial institutions worldwide. Journal of Corporate Finance 18,389-411.

Fama, E.F., Jensen, M.C., 1983. Separation of ownership and control. Journal of Law and Economics 26, 301-325.

Harris, M., Raviv, A., 2008. A theory of board control and size. Review of Financial Studies 21, $1797-1832$.

Hermalin, B.E., Weisbach, M.S., 1998. Endogenously chosen boards of directors and their monitoring of the CEO. The American Economic Review 88, 96-118.

Lewellyn, K.B., Muller-Kahle, M.I., 2012. CEO Power and Risk Taking: Evidence from the Subprime Lending Industry. Corporate Governance: An International Review 20, 289-307.

Malmendier, U., Tate, G., 2008. Who makes acquisitions? CEO overconfidence and the market's reaction. Journal of Financial Economics 89, 20-43.

Manconi, A., Massa, M., Yasuda, A., 2012. The role of institutional investors in propagating the 
crisis of 2007-2008. Journal of Financial Economics 104, 491-518.

May, D.O., 1995. Do managerial motives influence firm risk reduction strategies? The Journal of Finance 50, 1291-1308.

Monks, R., Minow, N., 1995. Corporate Governance. Blackwell, Cambridge, MA.

Morse, A., Nanda, V., Seru, A., 2011. Are incentive contracts rigged by powerful CEOs? Journal of Finance 66, 1779-1821

Onali, E., Galiakhmetova, R., Molyneux, P., Torluccio, G., 2016. CEO power, government monitoring, and bank dividends. Journal of Financial Intermediation 27, 89-117.

Pathan, S., 2009. Strong boards, CEO power and bank risk-taking. Journal of Banking and Finance 33, 1340-1350.

Shleifer, A., Vishny, R., 1997. A survey of corporate governance. Journal of Finance 52, 737783

Shleifer, A., Vishny, R., 1986. Large shareholders and corporate control. Journal of Political Economy 94, 461-488

Srivastav, A., Hagendorff, J., 2016. Corporate governance and bank risk taking. Corporate Governance: An International Review 24, 334-345.

Victoravich, L.M., Xu, P., Buslepp, W., Grove, H., 2011. CEO power, equity incentives, and bank risk taking. Available at SSRN: https $/ /$ ssrn.com/abstract=1909547

Yan, X., Z. Zhang, Z., 2009. Institutional investors and equity returns: are short-term institutions better informed? Review of Financial Studies 22, 893-924. 
Table 1

Descriptive statistics

\begin{tabular}{lcccccccc}
\hline Variables & $\mathrm{N}$ & Mean & $\mathrm{p} 25$ & Median & $\mathrm{p} 75$ & $\begin{array}{c}\text { Standard } \\
\text { deviation }\end{array}$ & Minimum & Maximum \\
\hline Default risk (z score) & 6405 & -7.92 & -9.67 & -7.66 & -5.29 & 4.800 & -76.40 & 6.06 \\
Systemic risk & 6405 & 0.48 & 0.00 & 0.32 & 0.95 & 0.796 & -21.56 & 13.19 \\
Systematic risk & 6405 & -1.24 & -2.23 & -0.72 & 0.01 & 3.163 & -20.00 & 20.00 \\
CEO power index & 6405 & 0.00 & -0.92 & -0.16 & 0.67 & 1.227 & 3.06 & 3.94 \\
Board Size & 6405 & 10.77 & 8.00 & 10.00 & 13.00 & 3.271 & 4.00 & 32.00 \\
Board Independence & 6405 & 0.78 & 0.71 & 0.80 & 0.87 & 0.117 & 0.26 & 0.95 \\
Institutional ownership & 6405 & 7.45 & 0.92 & 3.79 & 10.77 & 9.764 & 0.00 & 117.40 \\
Leverage & 6405 & 80.44 & 75.32 & 82.86 & 87.74 & 10.67 & 5.41 & 96.54 \\
Profitability & 6405 & 0.48 & 0.35 & 0.78 & 1.11 & 1.793 & -9.99 & 9.51 \\
Liquidity & 6405 & 22.61 & 14.30 & 20.90 & 29.02 & 11.935 & 0.33 & 86.52 \\
Loan provisions & 6405 & 0.21 & 0.03 & 0.08 & 0.19 & 0.459 & 0.01 & 5.41 \\
Capital & 6405 & 10.37 & 8.02 & 9.64 & 11.83 & 4.194 & 0.14 & 65.42 \\
Size & 6405 & 0.64 & -0.53 & 0.24 & 1.39 & 1.740 & -3.22 & 7.85 \\
\hline
\end{tabular}


Table 2

CEO power and bank risk: baseline estimates

\begin{tabular}{|c|c|c|c|c|c|c|}
\hline & \multicolumn{2}{|c|}{ Default risk } & \multicolumn{2}{|c|}{ Systematic risk } & \multicolumn{2}{|c|}{ Systemic risk } \\
\hline & $\begin{array}{l}\text { Fixed } \\
\text { effects }\end{array}$ & GMM & $\begin{array}{l}\text { Fixed } \\
\text { effects }\end{array}$ & GMM & $\begin{array}{l}\text { Fixed } \\
\text { effects }\end{array}$ & GMM \\
\hline Lag of risk indicator & & $\begin{array}{l}0.686^{* * * *} \\
(0.011)\end{array}$ & & $\begin{array}{l}0.277 * * * \\
(0.019)\end{array}$ & & $\begin{array}{l}0.402 * * * \\
(0.011)\end{array}$ \\
\hline CEO power & $\begin{array}{c}0.108 \\
(0.050)\end{array}$ & $\begin{array}{l}0.961 * * * \\
(0.164)\end{array}$ & $\begin{array}{c}0.035^{*} \\
(0.020)\end{array}$ & $\begin{array}{l}0.241^{* * *} * \\
(0.036)\end{array}$ & $\begin{array}{l}0.253^{* * *} * \\
(0.069)\end{array}$ & $\begin{array}{l}0.054 * * \\
(0.024)\end{array}$ \\
\hline Board size & $\begin{array}{l}-0.045^{* * *} \\
(0.012)\end{array}$ & $\begin{array}{l}-0.017 * * \\
(0.007)\end{array}$ & $\begin{array}{l}-0.004 \\
(0.005)\end{array}$ & $\begin{array}{l}-0.012 \\
(0.008)\end{array}$ & $\begin{array}{l}-0.016 \\
(0.025)\end{array}$ & $\begin{array}{l}-0.011 \\
(0.020)\end{array}$ \\
\hline Board independence & $\begin{array}{l}-0.032 \\
(0.024)\end{array}$ & $\begin{array}{l}-0.129 * * * \\
(0.023)\end{array}$ & $\begin{array}{l}-0.016^{*} \\
(0.009)\end{array}$ & $\begin{array}{l}-0.380 * * \\
(0.161)\end{array}$ & $\begin{array}{l}-0.030 \\
(0.038)\end{array}$ & $\begin{array}{l}-0.606^{* * * *} \\
(0.170)\end{array}$ \\
\hline Institutional ownership & $\begin{array}{l}0.002 \\
(0.004)\end{array}$ & $\begin{array}{l}0.010^{* * * *} \\
(0.003)\end{array}$ & $\begin{array}{l}0.006 * * * \\
(0.002)\end{array}$ & $\begin{array}{l}0.023 * * * \\
(0.002)\end{array}$ & $\begin{array}{c}0.003 \\
(0.006)\end{array}$ & $\begin{array}{l}0.005 * * * \\
(0.001)\end{array}$ \\
\hline Capital & $\begin{array}{l}-0.545^{* * *} * \\
(0.084)\end{array}$ & $\begin{array}{l}-0.131 * * \\
(0.011)\end{array}$ & $\begin{array}{l}-0.011 \\
(0.007)\end{array}$ & $\begin{array}{l}-0.021 * * * \\
(0.005)\end{array}$ & $\begin{array}{l}-0.022 \\
(0.026)\end{array}$ & $\begin{array}{l}-0.001 \\
(0.001)\end{array}$ \\
\hline Liquidity & $\begin{array}{l}-0.017 * * \\
(0.008)\end{array}$ & $\begin{array}{l}-0.013 * * \\
(0.006)\end{array}$ & $\begin{array}{l}-0.002 \\
(0.002)\end{array}$ & $\begin{array}{l}-0.006^{*} \\
(0.003)\end{array}$ & $\begin{array}{l}-0.014 * \\
(0.007)\end{array}$ & $\begin{array}{l}-0.014 * * * \\
(0.004)\end{array}$ \\
\hline Loan provision & $\begin{array}{c}0.042 \\
(0.161)\end{array}$ & $\begin{array}{l}1.120 * * * \\
(0.126)\end{array}$ & $\begin{array}{c}0.051 * \\
(0.027)\end{array}$ & $\begin{array}{l}0.034 \\
(0.065)\end{array}$ & $\begin{array}{c}0.078 \\
(0.071)\end{array}$ & $\begin{array}{l}0.107 * \\
(0.046)\end{array}$ \\
\hline Leverage & $\begin{array}{c}0.021 * \\
(0.012)\end{array}$ & $\begin{array}{l}0.006^{* * *} \\
(0.003)\end{array}$ & $\begin{array}{c}0.002 \\
(0.002)\end{array}$ & $\begin{array}{l}0.013 * * * \\
(0.002)\end{array}$ & $\begin{array}{c}0.011 \\
(0.011)\end{array}$ & $\begin{array}{l}0.007 * * \\
(0.003)\end{array}$ \\
\hline Profitability & $\begin{array}{l}-0.047 * * \\
(0.022)\end{array}$ & $\begin{array}{l}-0.290 * * * \\
(0.012)\end{array}$ & $\begin{array}{l}-0.010 * \\
(0.006)\end{array}$ & $\begin{array}{l}-0.011 \\
(0.013)\end{array}$ & $\begin{array}{l}-0.013 \\
(0.027)\end{array}$ & $\begin{array}{l}-0.003 \\
(0.012)\end{array}$ \\
\hline Size & $\begin{array}{l}0.255 \\
(0.332)\end{array}$ & $\begin{array}{l}0.255 \\
(0.273)\end{array}$ & $\begin{array}{c}0.027 \\
(0.071)\end{array}$ & $\begin{array}{l}0.082 \\
(0.109)\end{array}$ & $\begin{array}{l}0.687^{*} \\
(0.370)\end{array}$ & $\begin{array}{l}0.222 * * * \\
(0.055)\end{array}$ \\
\hline Cris is dummy & $\begin{array}{l}4.257 * * * \\
(0.566)\end{array}$ & $\begin{array}{l}2.655^{* * *} * \\
(0.055)\end{array}$ & $\begin{array}{c}0.038 \\
(0.117)\end{array}$ & $\begin{array}{l}0.065^{* * * *} \\
(0.021)\end{array}$ & $\begin{array}{l}3.297 * * * \\
(0.293)\end{array}$ & $\begin{array}{c}0.022 \\
(0.018)\end{array}$ \\
\hline $\mathrm{R}^{2}$ & 0.671 & & 0.291 & & 0.237 & \\
\hline Observations & 6405 & 5658 & 6330 & 5719 & 6327 & 5605 \\
\hline $\begin{array}{l}\text { Arellano-Bond test for } \\
\operatorname{AR}(2) \text { (p-value) }\end{array}$ & & 0.226 & & 0.612 & & 0.461 \\
\hline $\begin{array}{l}\text { Hansen test for } \\
\text { overidentification }\end{array}$ & & 0.883 & & 0.927 & & 0.941 \\
\hline
\end{tabular}


Table 3

CEO power and bank risk with governance interactions

\begin{tabular}{|c|c|c|c|c|c|c|c|c|c|c|c|c|}
\hline & \multicolumn{6}{|c|}{ Fixed effects } & \multicolumn{6}{|c|}{ GMM estimates } \\
\hline & \multicolumn{2}{|c|}{ Default risk } & \multicolumn{2}{|c|}{ Sy stematic risk } & \multicolumn{2}{|c|}{ Systemic risk } & \multicolumn{2}{|c|}{ Default risk } & \multicolumn{2}{|c|}{ Sy stematic risk } & \multicolumn{2}{|c|}{ Sy stemic risk } \\
\hline & 1 & 2 & 3 & 4 & 5 & 6 & 7 & 8 & 9 & 10 & 11 & 12 \\
\hline Lag of risk indicator & & & & & & & $\begin{array}{l}0.684^{* * * *} \\
(0.011)\end{array}$ & $\begin{array}{l}0.653^{* * * *} \\
(0.012)\end{array}$ & $\begin{array}{l}0.295^{* * *} \\
(0.018)\end{array}$ & $\begin{array}{l}0.295^{* * * *} \\
(0.018)\end{array}$ & $\begin{array}{l}0.406^{* * * *} \\
(0.011)\end{array}$ & $\begin{array}{l}0.400 * * * \\
(0.011)\end{array}$ \\
\hline CEO power & $\begin{array}{r}0.114 * \\
(0.000)\end{array}$ & $\begin{array}{r}0.113 * \\
(0.061)\end{array}$ & $\begin{array}{c}0.050 * * \\
(0.025)\end{array}$ & $\begin{array}{c}0.053 * * \\
(0.025)\end{array}$ & $\begin{array}{l}0.319 \text { *** } \\
(0.072)\end{array}$ & $\begin{array}{l}0.310^{\text {**** }} \\
(0.072)\end{array}$ & $\begin{array}{l}0.848^{* * * *} \\
(0.157)\end{array}$ & $\begin{array}{l}0.838^{* * * *} \\
(0.206)\end{array}$ & $\begin{array}{l}0.170 * * * \\
(0.025)\end{array}$ & $\begin{array}{l}0.181 * * * \\
(0.027)\end{array}$ & $\begin{array}{l}0.048 * * \\
(0.025)\end{array}$ & $\begin{array}{l}0.050 * * \\
(0.023)\end{array}$ \\
\hline CEO power* board size & $\begin{array}{l}-0.002 \\
(0.005)\end{array}$ & & $\begin{array}{l}-0.002 \\
(0.001)\end{array}$ & & $\begin{array}{l}-0.012 * * \\
(0.005)\end{array}$ & & $\begin{array}{l}-0.003 \\
(0.003)\end{array}$ & & $\begin{array}{l}-0.002 \\
(0.002)\end{array}$ & & $\begin{array}{l}-0.000 \\
(0.000)\end{array}$ & \\
\hline $\begin{array}{l}\text { CEO power* board } \\
\text { independence }\end{array}$ & & $\begin{array}{l}-0.003 \\
(0.006)\end{array}$ & & $\begin{array}{l}-0.003 \\
(0.002)\end{array}$ & & $\begin{array}{l}-0.014 * * \\
(0.007)\end{array}$ & & $\begin{array}{l}-0.000 \\
(0.004)\end{array}$ & & $\begin{array}{l}-0.004 \\
(0.003)\end{array}$ & & $\begin{array}{l}-0.001 \\
(0.002)\end{array}$ \\
\hline Board size & $\begin{array}{l}-0.039 * * * \\
(0.012)\end{array}$ & $\begin{array}{l}-0.039 * * * \\
(0.012)\end{array}$ & $\begin{array}{l}-0.006 \\
(0.005)\end{array}$ & $\begin{array}{l}-0.006 \\
(0.005)\end{array}$ & $\begin{array}{l}-0.014 \\
(0.025)\end{array}$ & $\begin{array}{l}-0.016 \\
(0.025)\end{array}$ & $\begin{array}{l}-0.013^{*} \\
(0.007)\end{array}$ & $\begin{array}{l}-0.010 \\
(0.008)\end{array}$ & $\begin{array}{l}-0.014 * * \\
(0.007)\end{array}$ & $\begin{array}{l}-0.014 * * \\
(0.007)\end{array}$ & $\begin{array}{l}-0.016 * * \\
(0.007)\end{array}$ & $\begin{array}{l}-0.016 * * \\
(0.007)\end{array}$ \\
\hline Board independence & $\begin{array}{l}-0.031 \\
(0.022)\end{array}$ & $\begin{array}{l}-0.031 \\
(0.022)\end{array}$ & $\begin{array}{l}-0.015^{*} \\
(0.009)\end{array}$ & $\begin{array}{l}-0.015^{*} \\
(0.009)\end{array}$ & $\begin{array}{l}-0.031 \\
(0.038)\end{array}$ & $\begin{array}{l}-0.033 \\
(0.038)\end{array}$ & $\begin{array}{l}-0.127 * * * \\
(0.023)\end{array}$ & $\begin{array}{l}-0.088 * * * \\
(0.025)\end{array}$ & $\begin{array}{l}-0.356 * * \\
(0.144)\end{array}$ & $\begin{array}{l}-0.362 * * \\
(0.146)\end{array}$ & $\begin{array}{l}-0.507 * * \\
(0.157)\end{array}$ & $\begin{array}{l}-0.496 * * * \\
(0.165)\end{array}$ \\
\hline Institutional ownership & $\begin{array}{l}0.000 \\
(0.004)\end{array}$ & $\begin{array}{l}0.000 \\
(0.004)\end{array}$ & $\begin{array}{l}0.006 * * * \\
(0.002)\end{array}$ & $\begin{array}{l}0.006 * * * \\
(0.002)\end{array}$ & $\begin{array}{c}0.003 \\
(0.006)\end{array}$ & $\begin{array}{c}0.003 \\
(0.006)\end{array}$ & $\begin{array}{l}0.010^{* * * *} \\
(0.003)\end{array}$ & $\begin{array}{l}0.013 * * \\
(0.003)\end{array}$ & $\begin{array}{l}0.022 * * * \\
(0.002)\end{array}$ & $\begin{array}{l}0.022 * * * \\
(0.002)\end{array}$ & $\begin{array}{l}0.005^{* * * *} \\
(0.001)\end{array}$ & $\begin{array}{l}0.005 * * * \\
(0.001)\end{array}$ \\
\hline Capital & $\begin{array}{l}-0.545^{* * * *} \\
(0.088)\end{array}$ & $\begin{array}{l}-0.545 * * * \\
(0.088)\end{array}$ & $\begin{array}{l}-0.010 \\
(0.007)\end{array}$ & $\begin{array}{l}-0.010 \\
(0.007)\end{array}$ & $\begin{array}{l}-0.029 \\
(0.026)\end{array}$ & $\begin{array}{l}-0.029 \\
(0.026)\end{array}$ & $\begin{array}{l}-0.132 * * * \\
(0.011)\end{array}$ & $\begin{array}{l}-0.153 * * * \\
(0.013)\end{array}$ & $\begin{array}{l}-0.021 \text { *** } \\
(0.005)\end{array}$ & $\begin{array}{l}-0.021 \text { *** } \\
(0.005)\end{array}$ & $\begin{array}{l}-0.001 \\
(0.001)\end{array}$ & $\begin{array}{l}-0.001 \\
(0.001)\end{array}$ \\
\hline Liquidity & $\begin{array}{l}-0.018^{* *} \\
(0.009)\end{array}$ & $\begin{array}{l}-0.018 * * \\
(0.009)\end{array}$ & $\begin{array}{l}-0.002 \\
(0.002)\end{array}$ & $\begin{array}{l}-0.002 \\
(0.002)\end{array}$ & $\begin{array}{l}-0.013 * \\
(0.007)\end{array}$ & $\begin{array}{l}-0.013 * \\
(0.007)\end{array}$ & $\begin{array}{l}-0.021 * * * \\
(0.007)\end{array}$ & $\begin{array}{l}-0.033 \text { *** } \\
(0.006)\end{array}$ & $\begin{array}{l}-0.006^{*} \\
(0.003)\end{array}$ & $\begin{array}{l}-0.006^{*} \\
(0.003)\end{array}$ & $\begin{array}{l}-0.014 * * * \\
(0.004)\end{array}$ & $\begin{array}{l}0.015^{* * * *} \\
(0.004)\end{array}$ \\
\hline Loan provisions & $\begin{array}{c}0.070 \\
(0.171)\end{array}$ & $\begin{array}{c}0.070 \\
(0.171)\end{array}$ & $\begin{array}{l}0.054 * * \\
(0.027)\end{array}$ & $\begin{array}{l}0.054 * * \\
(0.027)\end{array}$ & $\begin{array}{c}0.073 \\
(0.072)\end{array}$ & $\begin{array}{c}0.073 \\
(0.072)\end{array}$ & $\begin{array}{l}1.185^{\text {**** }} \\
(0.131)\end{array}$ & $\begin{array}{l}1.049 \text { *** } \\
(0.131)\end{array}$ & $\begin{array}{c}0.076 \\
(0.062)\end{array}$ & $\begin{array}{c}0.076 \\
(0.062)\end{array}$ & $\begin{array}{l}0.101^{* *} \\
(0.041)\end{array}$ & $\begin{array}{c}0.104 * \\
(0.042)\end{array}$ \\
\hline Leverage & $\begin{array}{c}0.020 * \\
(0.012)\end{array}$ & $\begin{array}{c}0.020 * \\
(0.012)\end{array}$ & $\begin{array}{c}0.001 \\
(0.002)\end{array}$ & $\begin{array}{l}0.001 \\
(0.002)\end{array}$ & $\begin{array}{c}0.011 \\
(0.011)\end{array}$ & $\begin{array}{c}0.011 \\
(0.011)\end{array}$ & $\begin{array}{c}0.006^{*} \\
(0.003)\end{array}$ & $\begin{array}{l}0.010 \text { *** } \\
(0.003)\end{array}$ & $\begin{array}{l}0.010 * * * \\
(0.002)\end{array}$ & $\begin{array}{l}0.010 * * * \\
(0.002)\end{array}$ & $\begin{array}{l}0.008 * * * \\
(0.003)\end{array}$ & $\begin{array}{l}-0.001 \\
(0.001)\end{array}$ \\
\hline Profitability & $\begin{array}{l}-0.047 * * \\
(0.023)\end{array}$ & $\begin{array}{l}-0.047 * * \\
(0.023)\end{array}$ & $\begin{array}{l}-0.012 * * \\
(0.006)\end{array}$ & $\begin{array}{l}-0.012 * * \\
(0.006)\end{array}$ & $\begin{array}{l}-0.012 \\
(0.027)\end{array}$ & $\begin{array}{l}-0.012 \\
(0.027)\end{array}$ & $\begin{array}{l}-0.287 * * * \\
(0.012)\end{array}$ & $\begin{array}{l}-0.259 * * * \\
(0.011)\end{array}$ & $\begin{array}{l}-0.004 \\
(0.013)\end{array}$ & $\begin{array}{l}-0.006 \\
(0.013)\end{array}$ & $\begin{array}{l}-0.002 \\
(0.012)\end{array}$ & $\begin{array}{l}-0.007) \\
(0.012)\end{array}$ \\
\hline Size & $\begin{array}{c}0.242 \\
(0.322)\end{array}$ & $\begin{array}{c}0.241 \\
(0.322)\end{array}$ & $\begin{array}{c}0.011 \\
(0.069)\end{array}$ & $\begin{array}{c}0.012 \\
(0.069)\end{array}$ & $\begin{array}{c}0.618 * \\
(0.373)\end{array}$ & $\begin{array}{c}0.609 \\
(0.373)\end{array}$ & $\begin{array}{c}0.290 \\
(0.278)\end{array}$ & $\begin{array}{c}0.065 \\
(0.289)\end{array}$ & $\begin{array}{c}0.076 \\
(0.101)\end{array}$ & $\begin{array}{c}0.074 \\
(0.102)\end{array}$ & $\begin{array}{l}0.234 * * * \\
(0.054)\end{array}$ & $\begin{array}{l}0.219 \text { *** } \\
(0.054)\end{array}$ \\
\hline Crisis dummy & $\begin{array}{l}4.242 * * * \\
(0.634)\end{array}$ & $\begin{array}{l}4.252 * * * \\
(0.635)\end{array}$ & $\begin{array}{c}0.039 \\
(0.123)\end{array}$ & $\begin{array}{c}0.027 \\
(0.123)\end{array}$ & $\begin{array}{l}3.262 * * * \\
(0.288)\end{array}$ & $\begin{array}{l}3.229 \text { *** } \\
(0.291)\end{array}$ & $\begin{array}{l}2.631 \text { *** } \\
(0.056)\end{array}$ & $\begin{array}{l}2.554 * * * \\
(0.065)\end{array}$ & $\begin{array}{l}0.076 * * * \\
(0.022)\end{array}$ & $\begin{array}{l}0.077 * * * * \\
(0.022)\end{array}$ & $\begin{array}{c}0.025 \\
(0.017)\end{array}$ & $\begin{array}{c}0.022 \\
(0.018)\end{array}$ \\
\hline $\mathrm{R}^{2}$ & 0.672 & 0.673 & 0.293 & 0.293 & 0.238 & 0.239 & & & & & & \\
\hline Observations & 6405 & 6405 & 6330 & 6330 & 6327 & 6327 & 5458 & 5458 & 5391 & 5391 & 5279 & 5279 \\
\hline $\operatorname{AR}(2) p$-value & & & & & & & 0.296 & 0.285 & 0.908 & 0.913 & 0.365 & 0.345 \\
\hline Hansen test & & & & & & & 0.845 & 0.855 & 0.996 & 0.996 & 0.945 & 0.946 \\
\hline
\end{tabular}

Note: Panel fixed effects estimates are unbalanced panel regressions with bank and time fixed effects; independent variables are lagged one period to mitigate endogeneity problems. $* * *, * *$, and * indicate statistical significance at the 1, 5 and $10 \%$ levels, respectively. GMM estimates are sy stem GMM. AR(2) is the Arellano-Bond test for the absence of autocorrelation of the error terms at second order. The Hansen test is the is for overidentification of restrictions. ***, **, and * indicate statistical significance at the 1,5 and $10 \%$ levels, respectively. 
Table 4

CEO power and bank risk with institutional ownership interaction

\begin{tabular}{|c|c|c|c|c|c|c|}
\hline & \multicolumn{2}{|c|}{ Default risk } & \multicolumn{2}{|c|}{ Systematic risk } & \multicolumn{2}{|c|}{ Systemic risk } \\
\hline & $\begin{array}{l}\text { Fixed } \\
\text { effects }\end{array}$ & GMM & $\begin{array}{l}\text { Fixed } \\
\text { effects }\end{array}$ & GMM & $\begin{array}{l}\text { Fixed } \\
\text { effects }\end{array}$ & GMM \\
\hline Lag of risk indicator & & $\begin{array}{l}0.678 * * * \\
(0.010)\end{array}$ & & $\begin{array}{l}0.283 * * * \\
(0.019)\end{array}$ & & $\begin{array}{l}0.426 * * * \\
(0.012)\end{array}$ \\
\hline CEO power & $\begin{array}{c}0.097 * \\
(0.053)\end{array}$ & $\begin{array}{l}0.628 * * * \\
(0.117)\end{array}$ & $\begin{array}{c}0.034 * \\
(0.020)\end{array}$ & $\begin{array}{l}0.226^{* * * *} \\
(0.037)\end{array}$ & $\begin{array}{c}0.206^{*} \\
(0.075)\end{array}$ & $\begin{array}{c}0.056^{*} \\
(0.024)\end{array}$ \\
\hline CEO power* institutional ownership & $\begin{array}{c}0.007 \\
(0.010)\end{array}$ & $\begin{array}{l}0.002 \\
(0.002)\end{array}$ & $\begin{array}{c}0.003 \\
(0.004)\end{array}$ & $\begin{array}{c}0.000 \\
(0.001)\end{array}$ & $\begin{array}{l}0.003^{* *} * \\
(0.001)\end{array}$ & $\begin{array}{l}0.005 * * \\
(0.003)\end{array}$ \\
\hline Board size & $\begin{array}{l}-0.044 * * * \\
(0.012)\end{array}$ & $\begin{array}{l}-0.018 * * * \\
(0.007)\end{array}$ & $\begin{array}{l}-0.005 \\
(0.005)\end{array}$ & $\begin{array}{l}-0.014^{*} \\
(0.008)\end{array}$ & $\begin{array}{l}-0.016 \\
(0.025)\end{array}$ & $\begin{array}{l}-0.004 \\
(0.007)\end{array}$ \\
\hline Board independence & $\begin{array}{l}-0.032 \\
(0.025)\end{array}$ & $\begin{array}{l}-0.130 \\
(0.022)\end{array}$ & $\begin{array}{l}-0.013 \\
(0.009)\end{array}$ & $\begin{array}{l}-0.349 * * \\
(0.157)\end{array}$ & $\begin{array}{l}-0.025 \\
(0.039)\end{array}$ & $\begin{array}{l}-1.087 * * * \\
(0.208)\end{array}$ \\
\hline Institutional ownership & $\begin{array}{l}0.002 \\
(0.004)\end{array}$ & $\begin{array}{l}0.010 * * * \\
(0.003)\end{array}$ & $\begin{array}{l}0.006^{* * *} \\
(0.002)\end{array}$ & $\begin{array}{l}0.022 * * * \\
(0.002)\end{array}$ & $\begin{array}{c}0.003 \\
(0.006)\end{array}$ & $\begin{array}{l}0.005^{* * * *} \\
(0.001)\end{array}$ \\
\hline Capital & $\begin{array}{l}-0.550 * * * \\
(0.087)\end{array}$ & $\begin{array}{l}-0.131 * * * \\
(0.011)\end{array}$ & $\begin{array}{l}-0.009 \\
(0.007)\end{array}$ & $\begin{array}{l}-0.020 * * * \\
(0.005)\end{array}$ & $\begin{array}{l}-0.024 \\
(0.026)\end{array}$ & $\begin{array}{l}-0.002 \\
(0.001)\end{array}$ \\
\hline Liquidity & $\begin{array}{l}-0.016 * \\
(0.008)\end{array}$ & $\begin{array}{l}-0.020 * * * \\
(0.005)\end{array}$ & $\begin{array}{l}-0.001 \\
(0.002)\end{array}$ & $\begin{array}{l}-0.006^{* *} \\
(0.003)\end{array}$ & $\begin{array}{l}-0.015 * * \\
(0.007)\end{array}$ & $\begin{array}{l}-0.010^{* *} * \\
(0.004)\end{array}$ \\
\hline Loan provisions & $\begin{array}{c}0.036 \\
(0.165)\end{array}$ & $\begin{array}{l}1.121 * * * \\
(0.118)\end{array}$ & $\begin{array}{l}0.057 * * \\
(0.027)\end{array}$ & $\begin{array}{c}0.063 \\
(0.027)\end{array}$ & $\begin{array}{c}0.077 \\
(0.072)\end{array}$ & $\begin{array}{c}0.017 \\
(0.045)\end{array}$ \\
\hline Leverage & $\begin{array}{l}0.023 * * \\
(0.012)\end{array}$ & $\begin{array}{l}0.009 * * * \\
(0.003)\end{array}$ & $\begin{array}{c}0.001 \\
(0.002)\end{array}$ & $\begin{array}{l}0.012 * * * \\
(0.002)\end{array}$ & $\begin{array}{c}0.014 \\
(0.011)\end{array}$ & $\begin{array}{c}0.005 \\
(0.003)\end{array}$ \\
\hline Profitability & $\begin{array}{l}-0.043 * * \\
(0.022)\end{array}$ & $\begin{array}{l}-0.290 * * * \\
(0.011)\end{array}$ & $\begin{array}{l}-0.012 * * \\
(0.006)\end{array}$ & $\begin{array}{l}-0.011 \\
(0.014)\end{array}$ & $\begin{array}{l}-0.018 \\
(0.028)\end{array}$ & $\begin{array}{c}0.022^{*} \\
(0.011)\end{array}$ \\
\hline Size & $\begin{array}{c}0.209 \\
(0.320)\end{array}$ & $\begin{array}{c}0.233 \\
(0.256)\end{array}$ & $\begin{array}{c}0.007 \\
(0.069)\end{array}$ & $\begin{array}{c}0.086 \\
(0.108)\end{array}$ & $\begin{array}{c}0.632 * \\
(0.376)\end{array}$ & $\begin{array}{l}0.162 * * \\
(0.065)\end{array}$ \\
\hline Cris is dummy & $\begin{array}{l}4.268 * * * \\
(0.560)\end{array}$ & $\begin{array}{l}2.636 * * * \\
(0.051)\end{array}$ & $\begin{array}{c}0.026 \\
(0.120)\end{array}$ & $\begin{array}{l}0.068^{* * * *} \\
(0.022)\end{array}$ & $\begin{array}{l}3.354 * * * \\
(0.294)\end{array}$ & $\begin{array}{c}0.017 \\
(0.019)\end{array}$ \\
\hline $\mathrm{R}^{2}$ & 0.673 & & 0.294 & & 0.238 & \\
\hline Observations & 6405 & 5418 & 6330 & 5353 & 6327 & 5242 \\
\hline AR (2) p-value & & 0.268 & & 0.816 & & 0.459 \\
\hline Hansen test & & 0.874 & & 0.993 & & 0.958 \\
\hline
\end{tabular}

Note: Panel fixed effects estimates are unbalanced panel regressions with bank and time fixed effects; independent variables are lagged one period to mitigate endogeneity problems. ***,**, and $*$ indicate statistical significance at the 1, 5 and $10 \%$ levels, respectively. GMM estimates are system GMM. AR (2) is the Arellano-Bond test for the absence of autocorrelation of the error terms at second order. The Hansen test is the is for overidentification of restrictions. $* * * * *$, and $*$ indicate statistical significance at the 1,5 and $10 \%$ levels, respectively. 
Table 5

The economic impact of CEO power and governance variables on bank risk

\begin{tabular}{|c|c|c|c|}
\hline & Default risk & Systematic risk & Systemic risk \\
\hline \multicolumn{4}{|c|}{ A. Baseline estimates (Table 2) } \\
\hline \multicolumn{4}{|c|}{ CEO power } \\
\hline Fixed effect & 0.133 & 0.043 & 0.310 \\
\hline GMM & 1.179 & 0.296 & 0.066 \\
\hline \multicolumn{4}{|l|}{ Board size } \\
\hline Fixed effect & -0.147 & - & - \\
\hline GMM & -0.056 & - & - \\
\hline \multicolumn{4}{|c|}{ Board independence } \\
\hline Fixed effect & - & -0.002 & - \\
\hline GMM & -0.015 & -0.044 & -0.071 \\
\hline \multicolumn{4}{|c|}{ Institutional ownership } \\
\hline Fixed effect & - & 0.059 & - \\
\hline GMM & 0.098 & 0.225 & 0.049 \\
\hline \multicolumn{4}{|c|}{ B CEO power and governance interactions (Tables 3 and 4) } \\
\hline \multicolumn{4}{|c|}{ CEO power*board independence } \\
\hline Fixed effect & - & - & -0.015 \\
\hline GMM & - & - & -0.017 \\
\hline \multicolumn{4}{|c|}{ CEO power*institutional ownership } \\
\hline Fixed effect & - & - & 0.293 \\
\hline GMM & - & - & 0.488 \\
\hline
\end{tabular}


Appendix Table 1

CEO power measure: principal components analysis

\begin{tabular}{lcccc}
\hline & $\begin{array}{c}\text { First } \\
\text { component }\end{array}$ & $\begin{array}{c}\text { Second } \\
\text { component }\end{array}$ & $\begin{array}{c}\text { Third } \\
\text { component }\end{array}$ & $\begin{array}{c}\text { Fourth } \\
\text { component }\end{array}$ \\
\hline CEO tenure & 0.308 & 0.917 & 0.198 & 0.161 \\
CEO ownership & 0.573 & -0.282 & -0.193 & 0.745 \\
CEO duality & 0.514 & -0.281 & 0.749 & -0.308 \\
CEO network size & 0.559 & 0.042 & -0.601 & -0.601 \\
& & & 0.817 & 0.722 \\
Eigenvalue & 1.500 & 0.961 & 0.204 & 0.180 \\
Proportion of variance explained & 0.375 & 0.240 & & \\
\hline
\end{tabular}

This table presents the results of applying principle components analysis to four proxies of power based on CEO ability to exercise decision-making power. CEO tenure is the number of years the CEO has served in position at given year. CEO ownership is a binary variable equal to 1 if the equity-based compensation of the CEO is greater than the direct compensation of the CEO at given year. CEO duality is a dummy variable equal to 1 if the CEO is also the Chairman in a given year. CEO network size is the number of CEO's with whom the selected CEO overlaps while in employment, other activities, or education roles at the same company, organization, or institution in a given year. The eigenvectors are reported in orthonormal form. 
Appendix Table 2

Data sources and variable definitions

\begin{tabular}{|c|c|c|}
\hline Variables & Source & Description \\
\hline Default risk & SNL Financial & $\begin{array}{l}\text { Return on assets plus capital as set ratio divided by total by the } \\
\text { standard deviation of return on as sets in a given year. }\end{array}$ \\
\hline Systemic bank risk & SNL Financial & $\begin{array}{l}\text { Coefficient of the return of S\&P } 500 \text { index in the estimation of the } \\
\text { two-index market model in a given year. }\end{array}$ \\
\hline Systematic risk & SNL Financial & Marginal expected shortfall in 5 percent worst days at given year. \\
\hline CEO power & $\begin{array}{l}\text { Authors } \\
\text { calculation }\end{array}$ & $\begin{array}{l}\text { Derived from the application of Principal Components Analysis to } \\
\text { four proxies for CEO power: CEO tenure; CEO ownership; CEO } \\
\text { duality; CEO network size }\end{array}$ \\
\hline Board size & BoardEx & The number of directors sitting on the board at given year. \\
\hline Board independence & BoardEx & $\begin{array}{l}\text { The percentage of independent non-executive directors on the board } \\
\text { at given year. }\end{array}$ \\
\hline Institutional ownership & $\begin{array}{l}\text { Thompson } \\
\text { One Banker }\end{array}$ & Percent of ownership by institutional investors in a given year \\
\hline Leverage & Call reports & $\begin{array}{l}\text { The ratio of total book value of liabilities to total as sets in a given } \\
\text { year. }\end{array}$ \\
\hline Profitability & Call reports & $\begin{array}{l}\text { The ratio of earnings before interest and taxes (to book value of total } \\
\text { as sets in a given year. }\end{array}$ \\
\hline Liquidity & Call reports & The ratio of liquid as sets to total as sets in a given year. \\
\hline Loan provisions & Call reports & The ratio of loan loss provision to total loans in a given year. \\
\hline Capital & Call reports & The ratio of risk-weighted capital to total as sets in a given year. \\
\hline Total assets & Call reports & Natural logarithm of total assets in a given year. \\
\hline Financial crisis dummy & $\begin{array}{l}\text { Authors' } \\
\text { calculation }\end{array}$ & $\begin{array}{l}\text { Binary variable that takes the value of one in a year of financial } \\
\text { crisis (2008 to 2010) and zero otherwise. }\end{array}$ \\
\hline
\end{tabular}

